TAO, Vol. 16, No. 5, 1079-1096, December 2005

\title{
Environmental Change in the Southwestern Coastal Plain of Taiwan Since Late Pleistocene: Using Multiple Proxies of Sedimentary Organic Matter
}

\author{
Huei-Wei Ku${ }^{1}$, Yue-Gau Chen ${ }^{1, *}$, and Tsung-Kwei Liu ${ }^{1}$
}

(Manuscript received 2 December 2003, in final form 3 August 2005)

\begin{abstract}
In an attempt to discriminate between organic matter sources and reconstruct further the paleoenvironment of the southwestern coastal plain of Taiwan, organic carbon and nitrogen content $(\mathrm{C} / \mathrm{N})$ ratios and isotope composition $\left(\delta^{13} \mathrm{C}\right.$ and $\left.\delta^{15} \mathrm{~N}\right)$ are measured for sedimentary core samples collected from San-liao-wan, Zai-kang and Yihju in the southwestern coastal plain of Taiwan. Heavy $\delta^{13} \mathrm{C}$ values (up to $-14.3 \%$ ) and high $\mathrm{C} / \mathrm{N}$ ratios (average 9.3) with good correlation indicate that this area underwent a period of relative aridity from early Marine Isotopic Stage (MIS) 2 to the early MIS 1. In MIS 1 , the $\delta^{13} \mathrm{C}$ and $\mathrm{C} / \mathrm{N}$ ratio both vary initially before later steadying, indicating that the environment became progressively more stable, with $\mathrm{C} 3$ plants becoming dominant again. The Zai-kang core appears to have come from a shallow lagoon system that potentially preserved the record of $\delta^{15} \mathrm{~N}$ from autochthonous primary producers. Regional organic source variation is revealed through the high $\delta^{15} \mathrm{~N}$ values and constant $\mathrm{C} / \mathrm{N}$ ratios in MIS 1 of the Zai-kang core. This may suggest that mangroves and macrophytes were the main aquatic organic matter source in the Zai-kang area during MIS 1.
\end{abstract}

(Key words: Organic matter, $\delta^{13} \mathrm{C}, \delta^{15} \mathrm{~N}, \mathrm{C} / \mathrm{N}$ ratios, Paleoenvironment, Coastal plain)

\section{INTRODUCTION}

Isotopic analysis and carbon to nitrogen ratios of bulk sediment organic matter are widely used to discriminate various organic sources in order to reconstruct depositional environments,

${ }^{1}$ Department of Geosciences, National Taiwan University, Taipei, Taiwan, ROC

* Corresponding author address: Prof. Yue-Gau Chen, Department of Geosciences, National Taiwan University, Taipei, Taiwan, ROC; E-mail: ygchen@ntu.edu.tw 
or vegetation changes (Tenzer et al. 1999; Schubert and Calvert 2001). In coastal areas, sedimentary sources vary and change rather often; thus, core sediments not only record organic matter change but also reflect regional environmental changes. The southwestern coastal plain of Taiwan initially formed during the late Pleistocene. It is covered by several hundred meters of alluvium captured by the gentle near-shore slope (Fig. 1). Wetlands, swamps, lagoons and sand bars developed commonly along the shallow shore area with the rivers noted for their high sand content and frequent avulsion. Thus, this area received an abundant supply of eroded

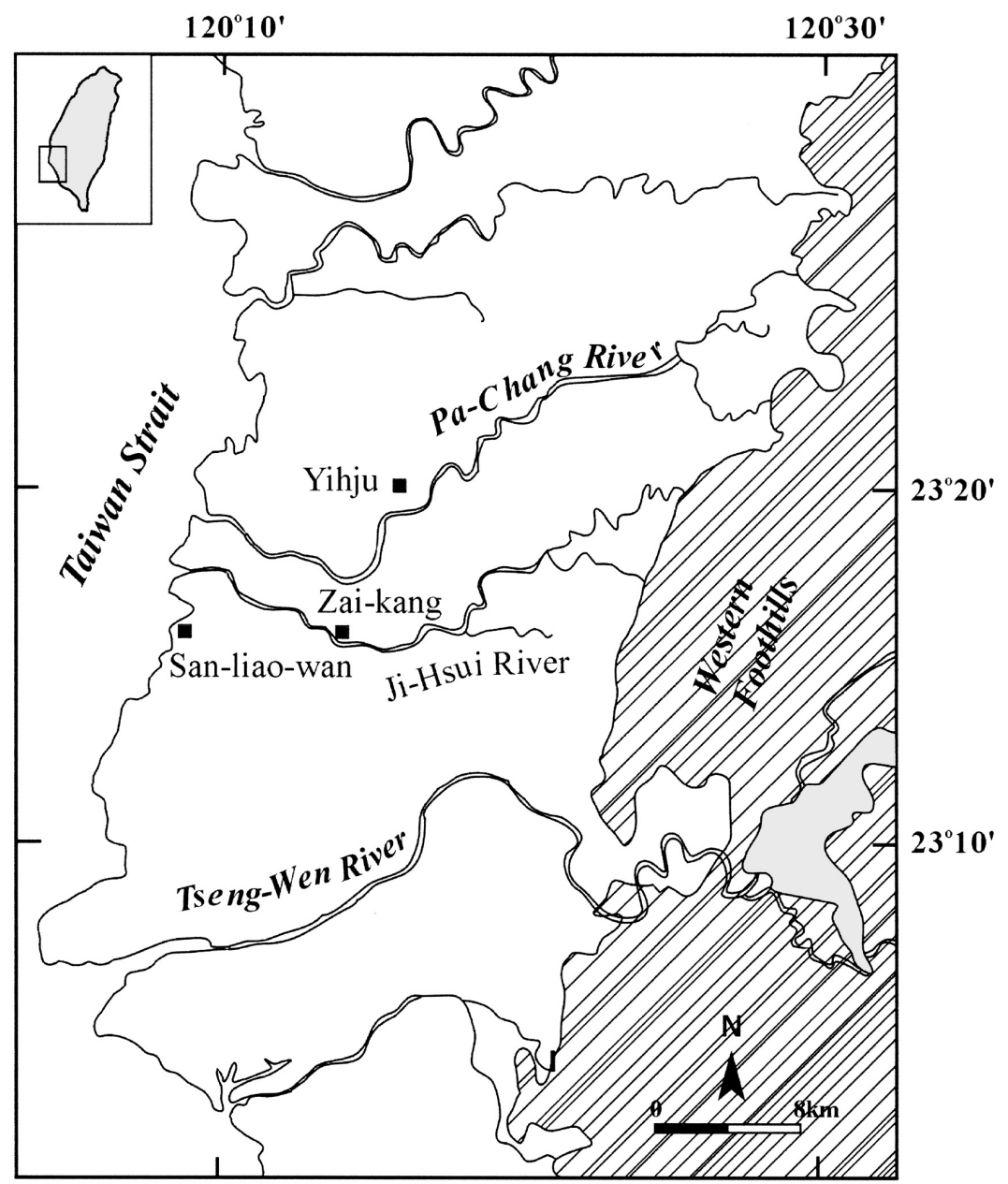

Fig. 1. Map showing the location of the San-liao-wan, Yihju, and Zai-kang cores in the southwestern coastal plain of Taiwan, which is bounded by the Western Foothills (right shaded area) and the Taiwan Strait in the east and west, respectively. 
terrestrial sediments such as sandstone, shale, and mudstone from the Western Foothills to the east. Geomorphologic features have changed significantly by such natural processes with the plain expanding continuously westward due to rapid sedimentation $\left(8 \mathrm{~mm} \mathrm{yr}^{-1}\right.$ since $3000 \mathrm{BP}$ for the Tseng-wen River) (Liu et al. 1997). Possible sources of sedimentary organic matter in this coastal area are: terrestrial biomass, soil and lithic fragments from higher land areas, and organic matter derived from in situ aquatic sources. In this study, not only $\delta^{13} \mathrm{C}$ and $\delta^{15} \mathrm{~N}$, but also bulk abundances of total organic carbon (TOC) and total or ganic nitrogen (TON) along with their atomic carbon to nitrogen ratios $(\mathrm{C} / \mathrm{N})$ are used to diagnose detailed information about the paleo-environment afforded by three-core samples taken from San-liao-wan, Zaikang and Yihju.

Bulk abundance of carbon and nitrogen (TOC and TON) has been used as the first-order indicator of organic matter flux and diagenesis interference (Meyers 1997). Although a large number of individual factors influence the TOC and TON of sediments, three master variables always apply: input flux of organic matter, diagenesis interference, and sedimentation rate (e.g., Tyson 1995). If the sedimentation rate is relatively steady over certain periods, high TOC and TON indicate increases in the input flux of organic matter. Furthermore, X-Y plotting of TON vs. TOC can be used to examine diagenesis degradation of carbon-coupled nitrogen (Schubert and Calvert 2001) to examine the reliability of study materials. The $\mathrm{C} / \mathrm{N}$ ratio has been verified as a good indicator of protein source content in sediments. Plants, in general, have higher $\mathrm{C} / \mathrm{N}$ ratios than animals due to their low protein and high cellulose content. The $\mathrm{C} / \mathrm{N}$ ratios of marine zooplankton and phytoplankton have an average value between $5 \sim 6$, whereas that of higher terrestrial plants are usually higher than 20 (Meyers 1997; Muller and Voss 1999). Bordovskiy (1965) concluded that a $\mathrm{C} / \mathrm{N}$ ratio of $<8$ indicates an origin of marine organic matter, while a ratio of $>12$ represents a terrestrial organic matter source.

Stable isotope ratios of organic carbon and nitrogen are useful tracers for delineating and identifying formation processes and sources of organic matter (Thornton and McManus 1994; Middelburg and Nieuwenhuize 1998). Organic carbon retains syn-depositional signals for source identification (Authur et al. 1988; Muller and Voss 1999) and is relatively conservative in comparison with nitrogen isotope values or $\mathrm{C} / \mathrm{N}$ ratios (Thornton and McManus 1994). The organic carbon preserved in coastal sediments is mainly derived from two sources: fragments of terrestrial plants and aquatic phytoplankton. These are characterized by different isotopic values (Deines 1980). The $\delta^{13} \mathrm{C}$ values of organic matter in modern marine sediments span a wide range. Previous studies indicate that the modern values are mostly in the range of $-19 \%$ to $-28 \%$ (Emerson and Hedges 1988; Hsieh et al. 2000). Terrestrial C3 and C4 plants, growing through different photosynthetic pathways, show distinct $\delta^{13} \mathrm{C}$ values: $\mathrm{C} 3$ : -26 to $-28 \%$; C4: -12 to $-14 \%$ (Deines 1980; O'Leary 1981). In general, C3 plants grow under humid conditions, while C4 types grow under relatively arid conditions. Ku Wei 1997 (pers. comm.) further suggested that the low sea-level interval period could be associated with increased $\delta^{13} \mathrm{C}$ in Taiwan. With good separation of isotope composition of different sources, increased $\delta^{13} \mathrm{C}$ correlates with a rise in $\mathrm{C} 4$ species population in the coastal area. Thus, $\delta^{13} \mathrm{C}$ can be used not only as an indicator of change in plant species populations but also as a good proxy for the history of sea-level change. 
The natural ratio of the two stable isotopes, ${ }^{15} \mathrm{~N}$ and ${ }^{14} \mathrm{~N}$, provides a means of tracing nitrogen sources among nutrient pools, and has been widely applied in environmental study (e.g., Macko and Ostrom 1994; Michener \& Schell 1994; Meyer 1997). Nitrogen availability in coastal systems constrains primary production. Nitrogen isotope ratios $\left(\delta^{15} \mathrm{~N}\right)$ range from $-3 \%$ for some plankton to more than $18 \%$ for complex aquatic organisms (Wada et al. 1975; Minagawa and Wada 1984). Initial studies of stable isotopes in estuaries and coastal environments compared the natural ratio of ${ }^{15} \mathrm{~N}$ and ${ }^{14} \mathrm{~N}$ in suspended particles from river and marine sites to identify the relative contribution of various sources to sedimentary organic matter based on the assumption of simple, two-component mixing (Peters et al. 1978). Seasonal and spatial variations in suspended particle $\delta^{15} \mathrm{~N}$ within estuaries suggested biological processes occurring in fresh, as well as seawater, apparently change isotopic ratios (Sigleo and Macko 1985; Owens 1985). On the other hand, terrestrial plants have a $\delta^{15} \mathrm{~N}$ range of -5 to $+18 \%$ with average of $+3 \%$ (Schoeninger and DeNiro 1984). The sedimentary $\delta^{15} \mathrm{~N}$ values in coastal areas are subject to the kinetic isotope fractionation effects during the biogenic metabolism of dissolved and particulate nitrogen compounds (Owens 1987). Major biogeochemical processes modifying the $\delta^{15} \mathrm{~N}$ of different nitrogen pools include ammonification, nitrification, denitrification, and nutrient assimilation, having the products isotopically lighter than substrates. Previous studies also suggest that the sedimentary record of $\delta^{15} \mathrm{~N}$ values could be used to infer the nature and fate of sinking organic matter from productivity in the past (Brandes and Devol 1997; Voss and Struck 1997).

Nineteen radiocarbon dates were obtained from in situ carbon collected from three study cores. The ages are plotted next to the columnar profiles in Figs. 2 - 4 and expressed as yr BP. The first grey line, representing the boundaries between Marine Isotope Stage (MIS) 1/2 (Martinson et al. 1987; Linsley and Dunbar 1994), is delineated based on the age results. The boundaries of MIS 2/3 are basically based on the characters of geochemical proxies in this study. The subsidence rate varies from core to core. Based on radiocarbon ages, there is a possible hiatus at MIS 2 in the three cores. Even so, each has records of every MIS, providing an opportunity to retrieve environmental clues left by co-depositional organic matter for the past $40 \mathrm{ka}$.

Previous sedimentological and foraminifera studies of southwestern coastal plants have found that the grain size of sediments were mostly on a sandy to muddy scale. The studies also documented that MIS 1 sediments accumulated under shallow sea to lagoonal environments, and were scattered with non-marine deposits in the lower parts (Figs. 2 - 4) (Liu and Hsia 1998). Organic geochemical study of biomarkers in the sediments of this area found no significant variation to identify different organic sources. This was due to the high content of reworked materials from the Western Foothills (Oung et al. 1996, 2001). Organic carbon isotope studies by Chen-chi Hsieh (1999) and Hong-wei Chiang (2000) (pers. comm.) previously demonstrated that the low sea-level period is associated with heavy $\delta^{13} \mathrm{C}$ values in the Sanliao-wan core and nearby area. First-order paleoenvironment information recorded in these studied cores is in response to the global glacial-interglacial transition. However, they used $\delta^{13} \mathrm{C}$ only meaning detail that could be revealed using a nitrogen context was unavailable to them. In this study, we use $\delta^{13} \mathrm{C}$ and $\delta^{15} \mathrm{~N}$ compositions along with elementary $\mathrm{C} / \mathrm{N}$ ratios of the organic matter in the three cores in an attempt to reconstruct the sedimentation history and 


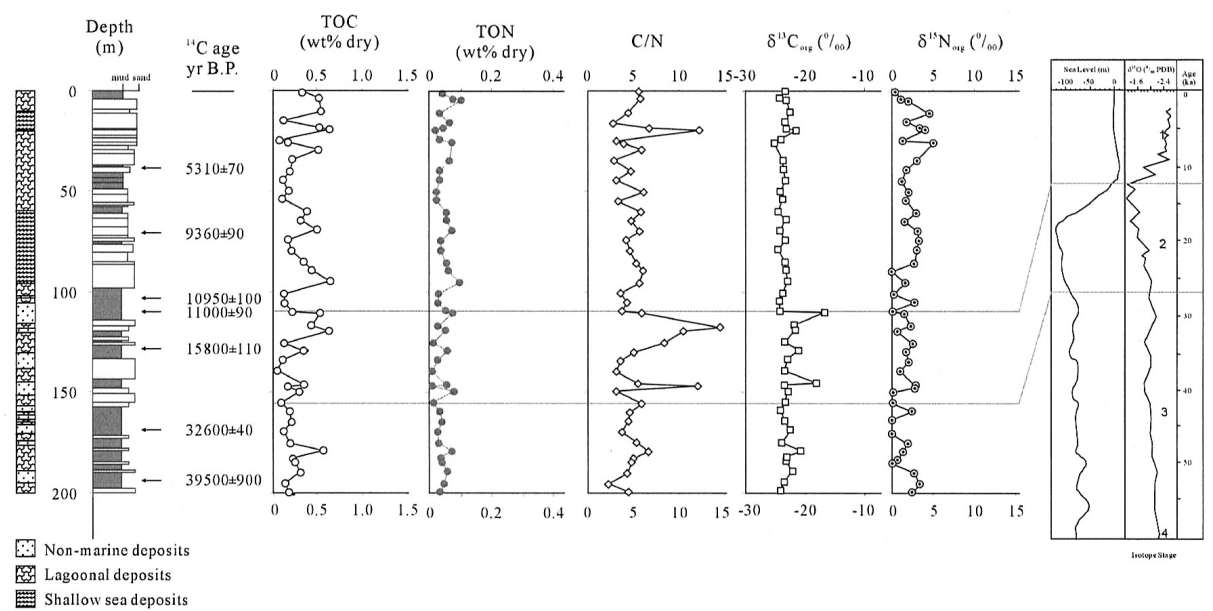

Fig. 2. Lithology, ${ }^{14} \mathrm{C}$ ages, and bulk chemistry of the sediments from the Sanliao-wan core. Downcore plots of total organic carbon (TOC), atomic carbon to nitrogen ratio $(\mathrm{C} / \mathrm{N}), \delta^{13} \mathrm{C}$ and $\delta^{15} \mathrm{~N}$ of organic matter are depicted. The oxygen isotope curve is excerpted from Linsley and Dunbar (1994). The sea-level curve is deduced from oxygen isotopes and calibrated by U/Th-dated reef terraces by Shackleton et al. (1983). Boundaries between MIS $1 / 2$ are delineated based on the age results. Boundaries of MIS $2 / 3$ are basically based on the characters of geochemical proxies in this study.

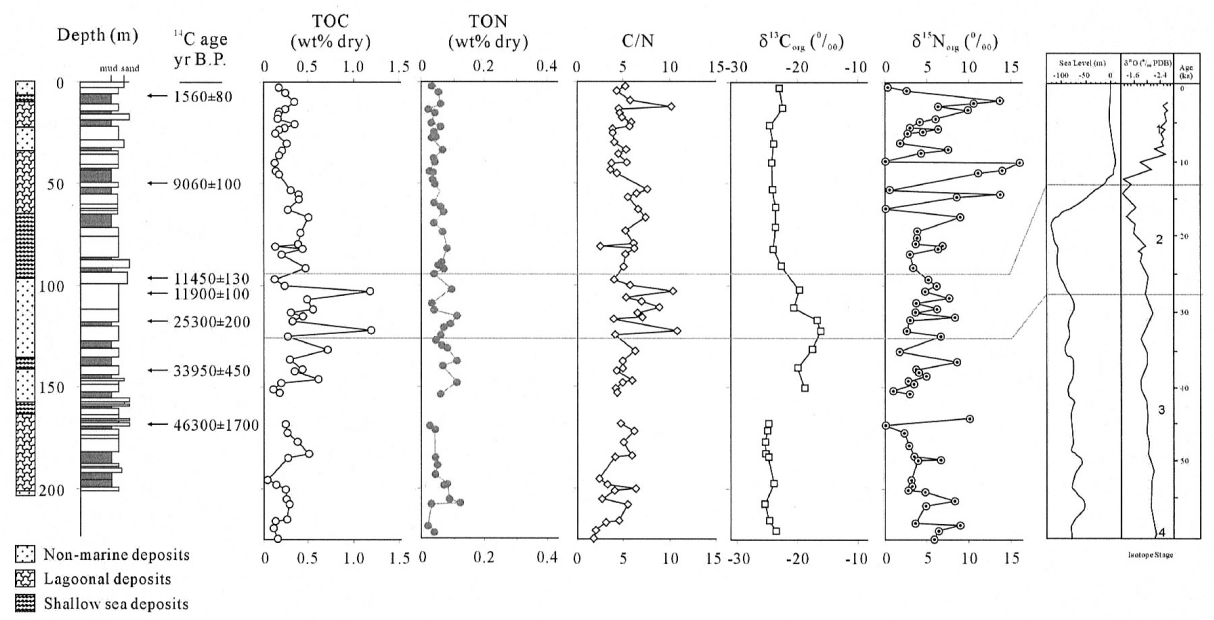

Fig. 3. Lithology, ${ }^{14} \mathrm{C}$ ages, and bulk chemistry of the sediments from the Zaikang core. Downcore plots of total organic carbon (TOC), atomic carbon to nitrogen ratio $(\mathrm{C} / \mathrm{N}), \delta^{13} \mathrm{C}$ and $\delta^{15} \mathrm{~N}$ of organic matter are depicted. 


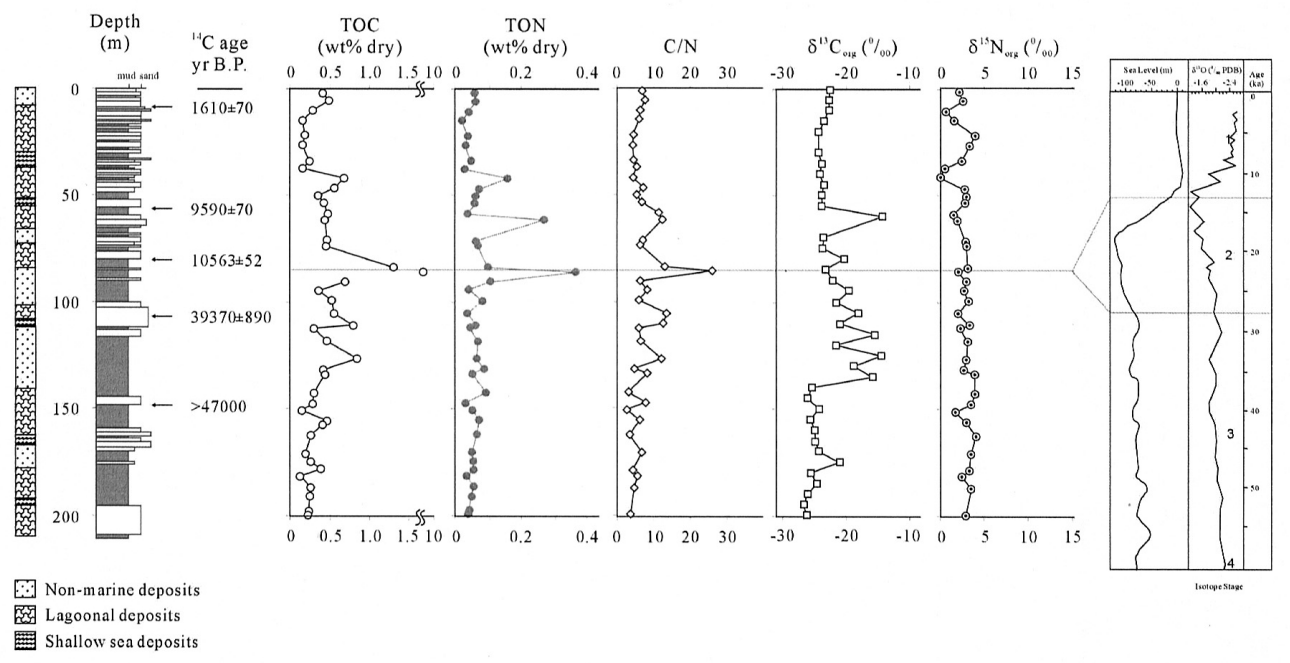

Fig. 4. Lithology, ${ }^{14} \mathrm{C}$ ages, and bulk chemistry of the sediments from the Yihju core. Downcore plots of total organic carbon (TOC), atomic carbon to nitrogen ratio $(\mathrm{C} / \mathrm{N}), \delta^{13} \mathrm{C}$ and $\delta^{15} \mathrm{~N}$ of organic matter are depicted.

changes in the paleoenvironment. The results contribute to better understanding of coastal environmental and climate change for the coastal plain of southwestern Taiwan.

\section{METHOD \& MATERIALS}

This study focuses on the sediments of cores. Three study cores were drilled in the coastal plain of southwestern Taiwan, regarded geologically as a foreland basin resulting from an arccontinental collision (Fig. 1). This area received eroded terrestrial sediments from the Western Foothills to its east. Drilling depths at San-liao-wan, Yihju, and Zai-kang sites were $200 \mathrm{~m}$, $200 \mathrm{~m}$, and $220 \mathrm{~m}$, respectively. Fresh plant tissues were collected from the estuary of the Tseng-wen River. The sediments were sampled at intervals of around $5 \mathrm{~m}$. Each sub-sample was dried at $60^{\circ} \mathrm{C}$ and then homogenized in an agate mortar.

For elemental content analysis, a portion of ground sample was wrapped in a tin capsule, and then combusted using ThermoQuest EA1110 elemental analyzer to measure the total nitrogen and carbon content (TN and TC). Carbonate was removed from the sub-sample by adding $2 \mathrm{~N}$ hydrochloric acid. When $\mathrm{CO}_{2}$ bubbling ceases, the samples were neutralized by de-ionized water and dried at $60^{\circ} \mathrm{C}$, again. The same combustion process was applied to measure total organic nitrogen and carbon content (TON and TOC).

For stable isotope analyses $\left(\delta^{15} \mathrm{~N}\right.$ and $\left.\delta^{13} \mathrm{C}\right)$, carbonate-free sample was combusted with an EA1110 CHNS analyzer connected via a Conflow to a Finnigan Delta Plus mass spectrometer. Pure $\mathrm{N}_{2}$ and $\mathrm{CO}_{2}$ gases from tanks were calibrated as reference standards against atmospheric nitrogen $(-2.8 \%)$ and USGS-24 graphite $(-16.0 \%)$, respectively. Outliers are 
analytically duplicated to verify that they are not analytical errors or artifacts. The errors for TOC and TON are $\pm 0.02 \mathrm{wt} \%$. The errors for carbon and nitrogen isotopic values are $\pm 0.1 \%$ and $\pm 0.2 \%$, respectively.

\section{RESULTS \& DISCUSSIONS}

\subsection{C/N Ratio and $\delta^{13} \mathrm{C}$ Alteration}

All data are tabulated in Tables 1 - 3 for the three cores, respectively. $\mathrm{C} / \mathrm{N}$ ratios vary considerably between the lowest value of 1.65 at depth $61.4 \mathrm{~m}$ and the highest of 26.1 at depth

Table 1. Results of total organic carbon and nitrogen (TOC and TON), C/N ratio, carbon and nitrogen isotopic values of San-liao-wan.

\begin{tabular}{|c|c|c|c|c|c|c|c|c|c|c|c|}
\hline Depth (m) & TOC $(\%)$ & TON $(\%)$ & $\mathrm{C} / \mathrm{N}$ & $\delta^{13} \mathrm{C}(\%$ & $\delta^{15} \mathrm{~N}(\%)$ & Depth (m) & TOC $(\%)$ & TON (\%) & $\mathrm{C} / \mathrm{N}$ & $\delta^{13} \mathrm{C}(\%)$ & $\delta^{15} \mathrm{~N}(\%)$ \\
\hline-0.3 & 0.30 & 0.05 & 6.61 & -23.2 & 0.5 & -105.1 & 0.13 & 0.03 & 4.96 & -24.3 & 2. \\
\hline-3.8 & 0.51 & 0.07 & 6.84 & -24.3 & 1.1 & -109.5 & 0.22 & 0.05 & 4.29 & -24.2 & -0 \\
\hline-4.5 & 0.54 & 0.10 & 5.26 & -23.1 & 2,0 & -110.6 & 0.53 & 0.08 & 6.93 & -16.7 & 1 \\
\hline-11 & 0.11 & 0.03 & 3.33 & -22.6 & 4.5 & -117.1 & 0.44 & 0.03 & 16.92 & -21.8 & 2 \\
\hline-15.5 & 0.53 & 0.07 & 8.00 & -23.2 & 2.28 & -119.5 & 0.62 & 0.05 & 12.38 & -21.5 & 0. \\
\hline-18.5 & 0.63 & 0.04 & 14.40 & -23.0 & 7.0 & -125.5 & 0.13 & 0.01 & 9.90 & -23.3 & 2. \\
\hline-19.5 & 0.07 & 0.02 & 3.57 & -21.5 & 4.04 & -129.5 & 0.34 & 0.06 & 5.88 & -21.1 & 1. \\
\hline-24.5 & 0.16 & 0.04 & 4.57 & -24.1 & 1.3 & -134.1 & 0.12 & 0.03 & 4.10 & -22.9 & 2. \\
\hline-25.7 & 0.22 & 0.07 & 3.00 & -25.1 & 5.0 & -139.5 & 0.04 & 0.01 & 3.67 & $-23,3$ & \\
\hline-34.5 & 0.22 & 0.07 & 3.31 & -23.7 & $3.0 \%$ & -146.2 & 0.35 & 0.05 & 6.50 & -18.0 & 2. \\
\hline-39.5 & 0.19 & 0.03 & 5.49 & -23.6 & 1.7 & -147.0 & 0.17 & 0.01 & 14.24 & -23.3 & 2 \\
\hline-44.5 & 0.12 & 0.03 & 3.62 & -23.2 & 1.2 & -149.5 & 0.29 & 0.08 & 3.70 & $-22,9$ & \\
\hline-50.5 & 0.18 & 0.03 & 7.08 & -24.1 & 2.11 & -155.1 & 0.10 & 0.01 & 6.98 & -23.4 & -0 \\
\hline-54.5 & 0.10 & 0.03 & 3.87 & -23.8 & 1.7 & -159.5 & 0.18 & 0.03 & 5.39 & -24.0 & 2 \\
\hline-60.5 & 0.38 & 0.06 & 6.77 & -24.6 & 2.9 & -164.5 & 0.21 & 0.04 & 5.23 & -23.4 & -1 \\
\hline-64.5 & 0.31 & 0.06 & 5.59 & -23.1 & 1.5 & -169.5 & 0.12 & 0.03 & 4.27 & -22.5 & -0 \\
\hline-69.5 & 0.48 & 0.07 & 6.59 & -24.1 & 3.1 & -175.3 & 0.19 & 0.03 & 6.18 & -23.8 & 4 \\
\hline-74.5 & 0.18 & 0.04 & 4.87 & -23.2 & 3.2 & -179.5 & 0.56 & 0.07 & 7.78 & -20.8 & \\
\hline-79.5 & 0.21 & 0.04 & 5.39 & -24.5 & 3.0 & -182.8 & 0.23 & 0.04 & 5.84 & -23.1 & \\
\hline-85.5 & 0.34 & 0.05 & 6.25 & -23.2 & 2.7 & -184.6 & 0.24 & 0.04 & 5.60 & -23.2 & -0 \\
\hline-89.5 & 0.43 & 0.06 & 7.03 & -23.2 & -0.5 & -189.5 & 0.30 & 0.06 & 5.06 & -22.2 & 2 \\
\hline-95.1 & 0.63 & 0.10 & 0.50 & -22.9 & 1.6 & -195.3 & 0.13 & 0.05 & 2.68 & -23.5 & 3 \\
\hline-101 & 0.13 & 0.03 & 4.23 & -23.7 & 0.2 & -199.5 & 0.17 & 0.03 & 5.14 & -24.1 & \\
\hline
\end{tabular}

average

TOC $\%$

TON $(\%)$

$\frac{\mathrm{C} / \mathrm{N}}{5.66}$

$\frac{\delta^{13} \mathrm{C} \%}{23.6}$
$\delta^{15} \mathrm{~N}(\%)$

MIS 2 (110.6-155.1m)

0.28

0.04

8.29

23.6

21.

5.32

$-23.1$

1.5

1.3 
Table 2. Results of total organic carbon and nitrogen (TOC and TON), C/N ratio, carbon and nitrogen isotopic values of Zai-kang.

\begin{tabular}{|c|c|c|c|c|c|c|c|c|c|c|c|}
\hline Depth (m) & $\operatorname{TOC}(\%)$ & $\operatorname{TON}(\mathrm{p})$ & $\mathrm{C} / \mathrm{N}$ & $\delta^{1.3} \mathrm{C}(\%)$ & $6^{15} \mathrm{~N}(\%)$ & Depth (m) & $\operatorname{TOC}(\%)$ & $\operatorname{TON}(\%)$ & $\mathrm{C} / \mathrm{N}$ & $\delta^{13} \mathrm{C}\left({ }^{\circ}{ }^{\circ}\right)$ & $\delta^{15} \mathrm{~N}(\%)$ \\
\hline-2.5 & 0.18 & 0.03 & 5.19 & -23.0 & 0.6 & -111.9 & 0.55 & 0.06 & 8.90 & -20.6 & 6.3 \\
\hline-5.0 & 0.24 & 0.06 & 4.27 & -22.8 & 2.8 & -113.9 & 0.31 & 0.05 & 6.58 & -20.1 & 3.7 \\
\hline-10.1 & 0.35 & 0.06 & 5.77 & -23.0 & 13.5 & -116.0 & 0.44 & 0.06 & 6.88 & -20.2 & 8.4 \\
\hline-12.5 & 0.26 & 0.03 & 10.21 & -22.5 & 6.3 & -117.5 & 0.32 & 0.08 & 3.91 & -16.8 & 3.1. \\
\hline-14.0 & 0.19 & 0.04 & 4.42 & -23.2 & 9.8 & -122.9 & 1.21 & 0.11 & 10.86 & -16.2 & 2.6 \\
\hline-18.5 & 0.17 & 0.03 & 4.88 & -23.2 & 6.2 & -125.1 & 0.27 & 0.07 & 4.05 & -17.2 & 6.8 \\
\hline-20.1 & 0.36 & 0.06 & 5.82 & -23.5 & 4.3 & -132.5 & 0.71 & 0.11 & 6.21 & -17.6 & 1.7 \\
\hline-22.4 & 0.23 & 0.04 & 5.70 & -24.5 & 3.1 & -137.4 & 0.31 & 0.06 & 5.02 & -18.1 & 8.7 \\
\hline-23.1 & 0.17 & 0.04 & 3.93 & -23.8 & 6.4 & -141.5 & 0.44 & 0.09 & 4.98 & -20.0 & 3.8 \\
\hline-24.5 & 0.18 & 0.05 & 3.76 & -24.0 & 4.7 & -142.5 & 0.35 & 0.08 & 4.29 & -19.8 & 4.0 \\
\hline-25.4 & 0.14 & 0.04 & 3.93 & -23.8 & 2.9 & -145.0 & 0.46 & 0.10 & 4.67 & -19.5 & 5.1 \\
\hline-30.4 & 0.27 & 0.07 & 4.04 & -24.0 & 1.9 & -147.0 & 0.62 & 0.10 & 5.98 & -18.3 & 2.8 \\
\hline-33.9 & 0.22 & 0.04 & 5.21 & -24.4 & 7.6 & -148.5 & 0.21 & 0.04 & 4.84 & -19.7 & 3.4 \\
\hline-35.5 & 0.19 & 0.04 & 4.42 & -24.1 & 4,3 & -151.5 & 0.12 & 0.03 & 4.16 & -18.8 & 1.0 \\
\hline-39.9 & 0.14 & 0.03 & 5.35 & -24.3 & 0.1 & -153.2 & 0.19 & 0.04 & 4.34 & -20.0 & 3.0 \\
\hline-40.4 & 0.14 & 0.04 & 3.74 & -24.3 & 16.1 & -165.2 & 0.21 & 0.05 & 4.56 & -22.9 & 10.2 \\
\hline-43.5 & 0.14 & 0.04 & 3.62 & -23.9 & 14.0 & -168.5 & 0.25 & 0.05 & 4.72 & -24.7 & 0.2 \\
\hline-45.3 & 0.19 & 0.04 & 4.43 & -23.5 & 11.2 & -172.5 & 0.27 & 0.04 & 6.13 & -25.0 & 2.5 \\
\hline-53.5 & 0.31 & 0.04 & 7.54 & -24.1 & 0.7 & -177.2 & 0.42 & 0.08 & 5.07 & -25.1 & 3.1 \\
\hline-55.5 & 0.40 & 0.06 & 6.50 & -23.5 & 13.8 & -177.6 & 0.35 & 0.07 & 4.93 & -25.4 & 2.5 \\
\hline-57.5 & 0.40 & 0.07 & 5.54 & -23.5 & 8.6 & -183.8 & 0.51 & 0.09 & 5.82 & -25.2 & 3.5 \\
\hline-62.5 & 0.27 & 0.04 & 6.61 & -23.6 & 0.3 & -185.4 & 0.39 & 0.12 & 3.18 & -24.9 & 6.8 \\
\hline-66.5 & 0.50 & 0.07 & 7.38 & -23.3 & 9.0 & -185.5 & 0.17 & 0.03 & 4.90 & -24.8 & 3.9 \\
\hline-73.9 & 0.42 & 0.08 & 5.22 & -23.6 & 4.0 & .195.5 & 0.05 & 0.02 & 2.37 & -25.0 & 3.2 \\
\hline-80.1 & 0.39 & 0.06 & 6.13 & -23.4 & 3,8 & -198.5 & 0.14 & 0.04 & 3.30 & -23.9 & 3.3 \\
\hline-81.2 & 0.13 & 0.05 & 2.45 & -23.4 & 6.9 & -200.5 & 0.39 & 0.06 & 6.26 & -23.1 & 2.9 \\
\hline-82.5 & 0.44 & 0.07 & 6.16 & -24.0 & 5.9 & -201.1 & 0.13 & 0.03 & 4.00 & -24.8 & 4.8 \\
\hline-85.1 & 0.21 & 0.04 & 5.22 & -23.0 & 2.9 & -205.7 & 0.26 & 0.09 & 2.75 & -25.3 & 8.3 \\
\hline-91.5 & 0.48 & 0.10 & 5.01 & -22.7 & 3.6 & -208.5 & 0.29 & 0.05 & 5.44 & -25.4 & 4.8 \\
\hline-97.5 & 0.14 & 0.03 & 4.02 & -23.2 & 5.2 & -216.5 & 0.27 & 0.06 & 4.56 & .24 .6 & 3.8 \\
\hline-100.3 & 0.24 & 0.04 & 5.80 & -20.1 & 6.1 & -217.4 & 0.14 & 0.04 & 3.12 & -25.1 & 9.0 \\
\hline-103.3 & 1.19 & 0.11 & 10.41 & -19.7 & 4.7 & -220.5 & 0.13 & 0.07 & 1.93 & -23.8 & 6.3 \\
\hline-106.7 & 0.48 & 0.09 & 5.23 & -21.1 & 7.7 & -224.5 & 0.16 & 0.09 & 1.80 & -24.8 & 5.9 \\
\hline-108.5 & 0.50 & 0.07 & 7.00 & -19.9 & 3.7 & & & & & & \\
\hline \multicolumn{4}{|l|}{ average } & \multicolumn{2}{|c|}{$\operatorname{TOC}(\%)$} & TON $(\%)$ & \multicolumn{2}{|c|}{$\mathrm{C} / \mathrm{N}$} & $\delta^{13} \mathrm{C}(\%)$ & \multicolumn{2}{|c|}{$\delta^{15} \times(\%)$} \\
\hline \multicolumn{4}{|c|}{ MIS I (2.5-91.5m) } & \multicolumn{2}{|l|}{0.27} & 0.05 & \multicolumn{2}{|c|}{5.26} & -23.6 & \multicolumn{2}{|r|}{6.0} \\
\hline \multicolumn{4}{|c|}{ MIS 2 (97.5-125.1m) } & \multicolumn{2}{|l|}{0.51} & 0.07 & \multicolumn{2}{|c|}{6.69} & -19.6 & \multicolumn{2}{|r|}{5.3} \\
\hline \multicolumn{4}{|c|}{$\operatorname{MIS} 3 \sim(132.5 \mathrm{~m} \sim)$} & \multicolumn{2}{|l|}{0.29} & 0.07 & \multicolumn{2}{|c|}{4.42} & -22.8 & \multicolumn{2}{|r|}{4.4} \\
\hline
\end{tabular}


Table 3. Results of total organic carbon and nitrogen (TOC and TON), C/N ratio, carbon and nitrogen isotopic values of Yihju.

\begin{tabular}{|c|c|c|c|c|c|c|c|c|c|c|c|}
\hline Depth (m) & TOC $(\%)$ & TON $(\%)$ & $\mathrm{CN}$ & $\delta^{13} \mathrm{C}(\%)$ & $\delta^{15} \mathrm{~N}(\%$ & Depth (m) & TOC $(\%)$ & TON $(\%)$ & $\mathrm{CN}$ & $8^{13} \mathrm{C}\left(\%_{(w)}\right.$ & $\delta^{15} N(\%)$ \\
\hline-1.7 & 0.41 & 0.06 & 6.87 & -22.5 & 2.2. & -94.3 & 0.36 & 0.04 & 8.24 & -19.5 & 2.7 \\
\hline-5.4 & 0.49 & 0,06 & 7.71 & $-22,7$ & 2.6 & -99.5 & 0.52 & 0.09 & 6.09 & -21.4 & 3,2 \\
\hline-10.4 & 0.28 & 0.04 & 6.39 & -22.7 & 0.7 & -105.2 & 0.55 & 0.04 & 13.58 & -18.1 & 2.0 \\
\hline-14.7 & 0.15 & 0.02 & 6.05 & -23.5 & 1.6 & -110.6 & 0.80 & 0.06 & 12.55 & -21.0 & 3.3 \\
\hline-21.7 & 0.18 & 0.04 & 4.54 & -24.3 & 3.9 & -112.1 & 0.29 & 0.05 & 5.96 & -15.3 & 2.3 \\
\hline-26.4 & 0.15 & 0.03 & 4.34 & -24.3 & 3.3 & -118.4 & 0.46 & 0.07 & 6.61 & -21.7 & 3.1 \\
\hline-33.6 & 0.24 & 0.05 & 4.63 & -24.3 & 2.4 & -126.6 & 0.84 & 0.07 & 12.11 & -14.4 & 3.0 \\
\hline-37.2 & 0.16 & 0.03 & 5.38 & -23.8 & 0.5 & -131.6 & 0.41 & 0.09 & 4.67 & -18.7 & 2.6 \\
\hline-41.6 & 0.68 & 0.16 & 4.29 & -24.1 & -0.4 & -133.6 & 0.44 & 0.05 & 8.27 & -15.8 & 3.9 \\
\hline-46.6 & 0.55 & 0.08 & 7.31 & -23.5 & 2.8 & -142.5 & 0.29 & 0.09 & 3.11 & -25.3 & 3.9 \\
\hline-50.2 & 0.35 & 0.07 & 5.31 & -23.8 & 3.0 & -147.5 & 0.28 & 0.04 & 7.96 & -26.0 & 3.5 \\
\hline-53.3 & 0.42 & 0.06 & 6.93 & -23.8 & 2.8 & -150.8 & 0.14 & 0.05 & 2.63 & -24.2 & 1.7 \\
\hline-58.5 & 0.48 & 0.04 & 11.47 & -14.3 & 1.5 & -155.6 & 0.46 & 0.07 & 6.23 & -25.5 & 3.0 \\
\hline-61.4 & 0.44 & 0.27 & 1.65 & -16.2 & 1.9 & -162.2 & 0.25 & 0.07 & 3.75 & -24.9 & 4.1 \\
\hline .71 .2 & 0.46 & 0.07 & 7.03 & -23.5 & 2.9 & -170.3 & 0.19 & 0.05 & 3.48 & -24.3 & 3.5 \\
\hline-73.5 & 0.45 & 0.07 & 6.45 & -23.7 & 3.0 & -178.6 & 0.38 & 0.06 & 6.75 & -21.2 & 3.3 \\
\hline-83.6 & 1.31 & 0.10 & 12.98 & -20.3 & 3.1 & -181.4 & 0.11 & 0.04 & 2.96 & -25.5 & 2.5 \\
\hline-85.6 & 9.44 & 0.36 & 26.10 & -23.2 & 2.1 & -186.7 & 0.25 & 0.06 & 4.44 & -24.6 & 3.5 \\
\hline-90.5 & 0.69 & 0.11 & 6.41 & -22.1 & 3.0] & -199.4 & 0.22 & 0.04 & 5.64 & -26.1 & 2.9 \\
\hline
\end{tabular}

\begin{tabular}{lccccc} 
average & TOC $(\%)$ & TON $(\%)$ & $\mathrm{CN}$ & $\delta^{13} \mathrm{C}(\%)$ & $\delta^{15} \mathrm{~N}(\%)$ \\
\hline MIS 1 $(1.7-83.6 \mathrm{~m})$ & 0.42 & 0.07 & 6.43 & -22.4 & 2.2 \\
MIS 2 $(85.6 \mathrm{~m})$ & 9.44 & 0.36 & 26.10 & -23.2 & 2.1 \\
MIS 2-3 $(90.5-133.6 \mathrm{~m})$ & 0.54 & 0.07 & 8.45 & -18.8 & 2.9 \\
MIS 3 (142.5m $)$ & 0.26 & 0.06 & 4.70 & -24.8 & 3.2
\end{tabular}

$85.6 \mathrm{~m}$ in the Yihju core (Table 3). The values are generally higher during MIS 2 (average 8.29 for the San-liao-wan core, 6.69 for the Zai-kang core, and 8.45 for the Yihju core) (Tables $1-3$ ), and lower in the remaining areas of the cores. $\delta^{13} \mathrm{C}$ values for all three cores range between -26.1 and $-14.3 \%$, showing relatively heavy $\delta^{13} \mathrm{C}$ values (up to $-15 \%$ ) in the same intervals corresponding to high $\mathrm{C} / \mathrm{N}$ ratios. During the Holocene and MIS 3, the values are close to $-22.0 \%$ similar to values derived from modern shallow marine and lagoon sediments (Fontugne and Jonanneau 1987; Wada et al. 1987). The reasons for some low organic matter content are probably dilution effect caused by a high sedimentation rate and poor preservation of fresh organic matter, especially in the coastal/fluvial environment of Taiwan (Oung et al. 2001). Neither TOC nor TON decreases downcore (Figs. 2 - 4) and most points generally fall along a line pointing to origin in the TOC-TON plot (Fig. 5); thus no evidence is found for selective loss of either $\mathrm{C}$ or $\mathrm{N}$ with time. 


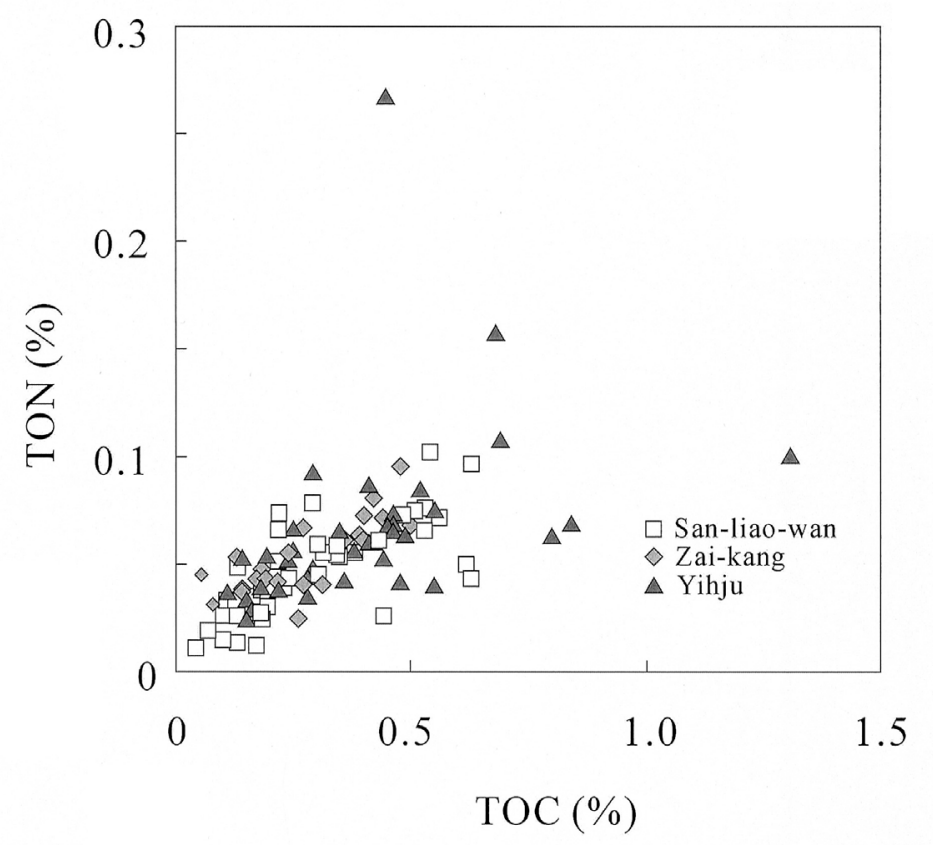

Fig. 5. Plot of TON vs. TOC. Depth $85.6 \mathrm{~m}$ of the Yihju core with TOC $=9.44 \%$ and $\mathrm{TON}=0.36 \%$ is not shown on this figure.

The $\mathrm{C} / \mathrm{N}$ ratio is often used as an indicator of organic matter sources. Results generally fall within the range of marine zooplankton and phytoplankton with occasionally high values in the range of strong terrestrial input (>10). The correspondence of high $\mathrm{C} / \mathrm{N}$ ratios and high TOC may indicate a coupling between higher fluxes of organic matter and improved preservation of its carbon content (Twichell et al. 2002). In the Yihju core, high TOC values (of 1.3 and 9.4\%) along with high $\mathrm{C} / \mathrm{N}$ ratios (of 13 and 26.1) but with no significant $\delta^{13} \mathrm{C}$ variation at around a depth of $80 \mathrm{~m}$ (Table 3, Fig. 4) may indicate an abrupt enhanced runoff of fresh surface sediments or soil C3 materials with high carbon content.

$\delta^{13} \mathrm{C}$ value is also an indicator of organic matter source and can be linked to climate change. Both the San-liao-wan and Zai-kang cores show trends of increased $\delta^{13} \mathrm{C}$ values and $\mathrm{C} / \mathrm{N}$ ratios in MIS 2 (Figs. 2, 3). This means the coastal area underwent a period with heavy $\delta^{13} \mathrm{C}$ values and high $\mathrm{C} / \mathrm{N}$ ratios, implying terrestrial input increased, and $\mathrm{C} 4$ plant species were an important source of this organic matter. The nature of the relatively cold climate extended into early MIS 1 in this area. The plot of $\mathrm{C} / \mathrm{N}$ vs. $\delta^{13} \mathrm{C}$ demonstrates that the organic matter source is mainly from a similar source of low $\mathrm{C} / \mathrm{N}$ and stable $\delta^{13} \mathrm{C}$ such as autochthonous primary producers (Fig. 6). The trend of terrestrial input toward high $\delta^{13} \mathrm{C}$ and $\mathrm{C} / \mathrm{N}$ (i.e., $\mathrm{C} 4$ species end members), is such that the terrestrial input of plant tissue with high $\mathrm{C} / \mathrm{N}$ in this area is strong enough to show the main climate shift through C3 - C4 plant species transition. 


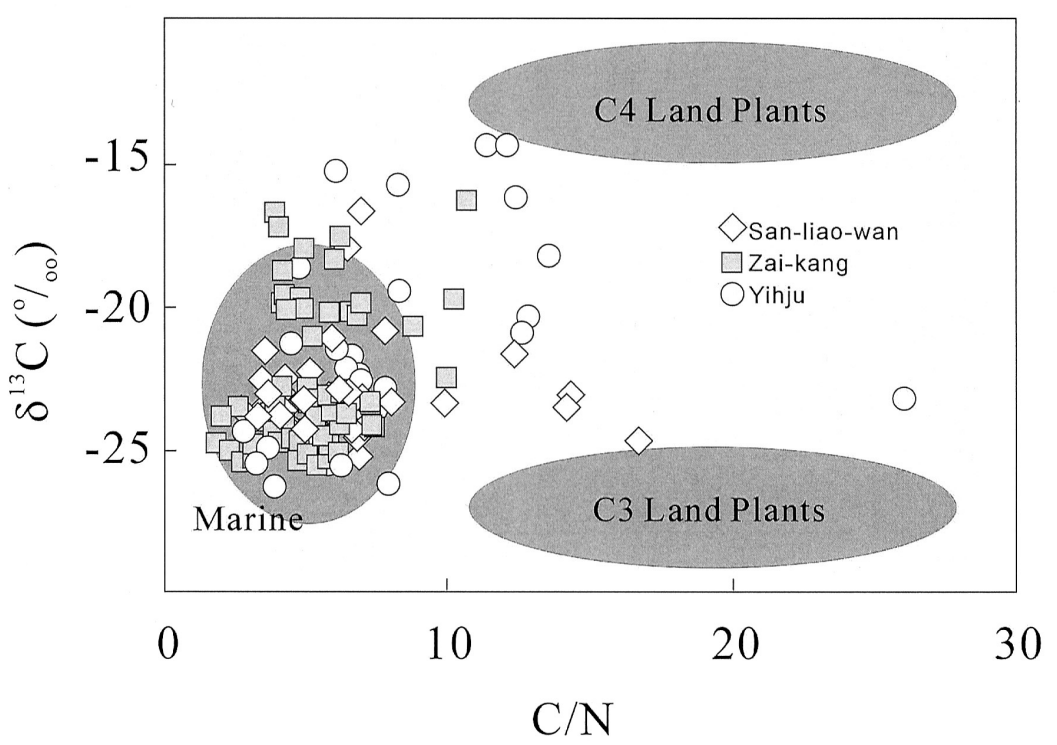

Fig. 6. Comparison of $\delta^{13} \mathrm{C}$ and atomic $\mathrm{C} / \mathrm{N}$ values of sediment samples to elemental and isotopic indicators of bulk organic matter produced by aquatic algae, C3, and C4 land plants. Shaded areas are end members of marine algae, C3, and C4 land plants (adapted from Meyers 1994).

\section{$3.2{ }^{15} \mathrm{~N}$ Enrichment in the Organic Sources}

The $\delta^{15} \mathrm{~N}$ values of the San-liao-wan and Yihju cores vary within a narrow range of $-1.0-5.0 \%$ throughout the cores centered around 2.1\% and 2.7\%, respectively (Figs. 2, 4). Values of $\delta^{15} \mathrm{~N}$ for the Zai-kang core fluctuate from 0.1 to $16.1 \%$ in MIS 1 but become relatively stable (average 4.6\% ) in the lower part of the core (Table 2, Fig. 3). The dissimilarity in $\delta^{15} \mathrm{~N}, \delta^{13} \mathrm{C}$ and $\mathrm{C} / \mathrm{N}$ ratios when comparing the Zai-kang core with the other two cores may be attributed to differences in sediment composition. The environment at Zai-kang when sediments accumulated may have been a relatively stable water body (e.g., lagoon), making $\delta^{15} \mathrm{~N}$ variation record easily recognizable. By contrast, the San-liao-wan and Yihju areas were subject to stronger influence from terrestrial input diluting marker signals as discussed in the introduction.

The broad range of $\delta^{15} \mathrm{~N}$ in the Zai-kang core during MIS 1 (up to $16.1 \%$, Table 2) is distinctly different from other parts of the Zai-kang core and the other two cores. Using plots of $\delta^{15} \mathrm{~N}$ vs. $\mathrm{C} / \mathrm{N}$ and $\delta^{15} \mathrm{~N}$ vs. $\delta^{13} \mathrm{C}$, enriched ${ }^{15} \mathrm{~N}$ input in this core can be clearly detected (Figs. 7, 8). This implies a different ${ }^{15} \mathrm{~N}$-enriched organic matter source in the above mentioned time periods. Based on independent study on sedimentary facies, MIS 1 is thought to be lagoon, in which the possible reasons for high $\delta^{15} \mathrm{~N}$ value are a DIN (dissolved inorganic nitrogen) source change, early sedimentary diagenesis, and high aquatic productivity. In a 


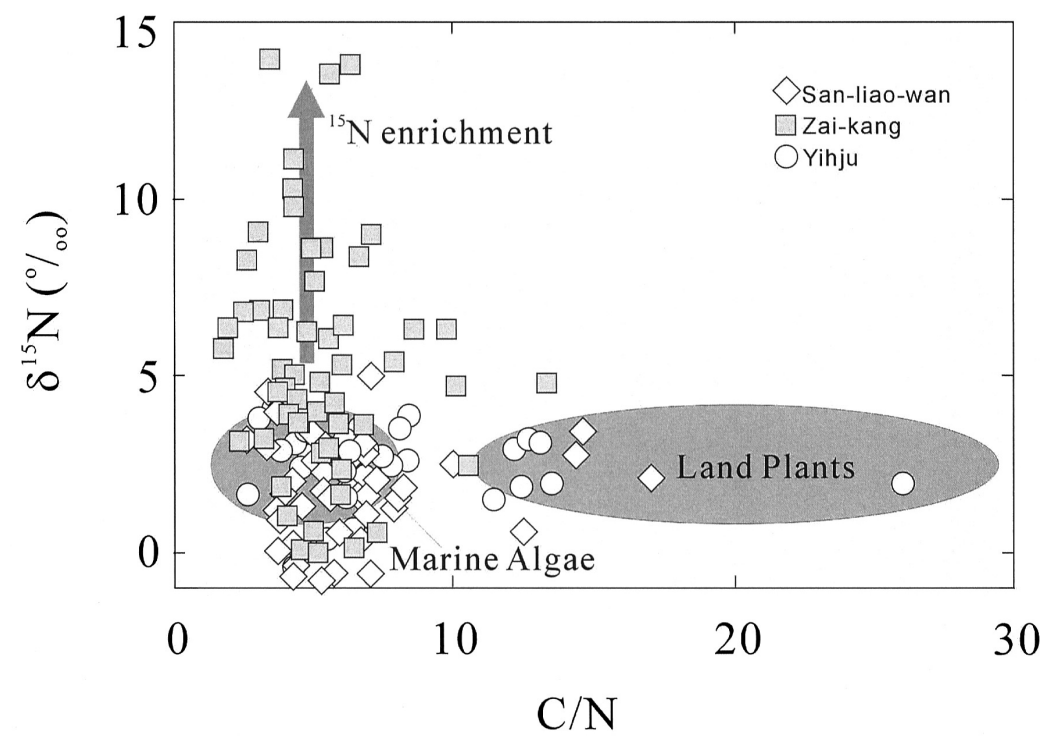

Fig. 7. Plot of $\delta^{15} \mathrm{~N}$ vs. $\mathrm{C} / \mathrm{N}$ ratios of sediment samples. Shaded areas are end members of marine algae, $\mathrm{C} 3$, and $\mathrm{C} 4$ land plants, and the direction of ${ }^{15} \mathrm{~N}$ enrichment.

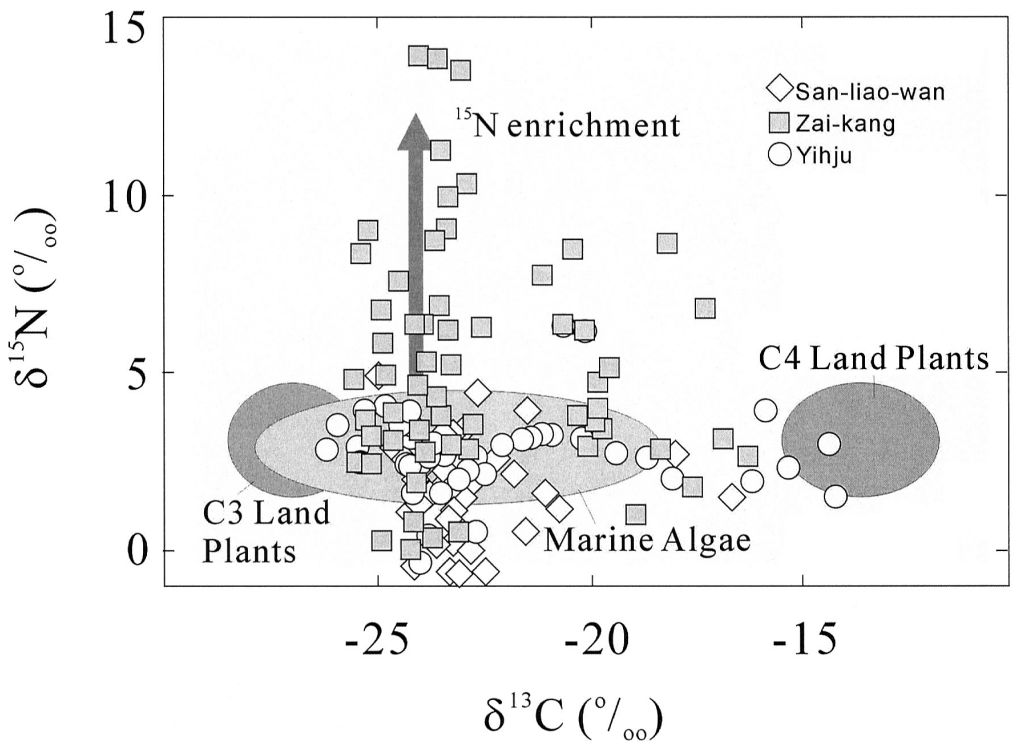

Fig. 8. Plot of $\delta^{15} \mathrm{~N}$ vs. $\delta^{13} \mathrm{C}$ of sediment samples. Light and dark shaded areas are end members of marine algae, $\mathrm{C} 3$, and $\mathrm{C} 4$ land plants, and the direction of ${ }^{15} \mathrm{~N}$ enrichment. 
similar environment, the possible reasons leading to high $\delta^{15} \mathrm{~N}$ value of sedimentary organic matter involve early sedimentary diagenesis, high aquatic productivity, and DIN (dissolved inorganic nitrogen) source change. Isotopic fractionation during decomposition is typically thought to result in the heavy isotopic composition of residual material (Ostrom et al. 1997; Sachs and Repeta 1999). In this study, early diagenesis might be neglected as discussed previously.

In most sedimentary environments, the source of nitrogen for primary production is limited. Thus, primary producers tend to assimilate most DIN, giving $\delta^{15} \mathrm{~N}$ values of organic matter close to source DIN (Horrigan et al. 1990; Altabet and Francois 1994). If the origin of DIN has been enriched in ${ }^{15} \mathrm{~N}$ by certain processes, the final organic products will show high $\delta^{15} \mathrm{~N}$ values. Denitrification, for instances, occurs under suboxic or anoxic conditions, causing a large fractionation factor $\alpha \leq 1.04$ and gives residual nitrate much higher $\delta^{15} \mathrm{~N}$ values, e.g., +15 to $+30 \%$ (Handley and Raven 1992; Michener and Schell 1994). Later utilization of residual nitrate from the denitrification of primary producers would result in heavier $\delta^{15} \mathrm{~N}$ values (Altabet et al. 1999; Ganeshram et al. 2000; Emmer and Thunell 2000).

The last reason is increased aquatic productivity. In general, high $\delta^{15} \mathrm{~N}$ values may indicate high aquatic productivity. High $\delta^{15} \mathrm{~N}$ and low $\mathrm{C} / \mathrm{N}$ ratios in the sediments of estuarine cores demonstrate an increase in autochthonous organic matter input such as macrophytes (Muller and Voss 1999). At the beginning of MIS 1, seawater inundated the Zai-kang area tuning it into a lagoon, which may have been a habit for mangroves and macrophytes much like the present-day estuary of Tseng-wen River. Analyzed results of fresh materials collected from Tseng-wen estuary and nearby lagoon (Table 4) well support this hypothesis with aquatic macrophytes from estuary and surface sediments of the lagoon showing relatively high $\delta^{15} \mathrm{~N}$ values. The surface sediments have average $\delta^{15} \mathrm{~N}$ value of $10.7 \%\left(\delta^{13} \mathrm{C}=-24.0 \%\right)$. An average $\delta^{15} \mathrm{~N}$ value of $9.6 \%{ }_{0}\left(\delta^{13} \mathrm{C}=-25.5 \%\right)$ was measured from Entermorpha intestinalis, while an average value of $8.7 \%\left(\delta^{13} \mathrm{C}=-24.7 \%\right.$ ) was found for samples of Ulva sp.

Thus, the results suggest that after a period when the sedimentation rate was high, at the beginning of MIS 1, the Zai-kang area became a semi-enclosed, shallow water lagoon system.

Table 4. Abundance and isotopic composition of plants collected from Tsengwen modern estuary and nearby lagoon.

\begin{tabular}{lrrrrr}
\hline & TOC $(\%)$ & TON $(\%)$ & \multicolumn{1}{c}{$\mathrm{C} / \mathrm{N}$} & $\delta^{13} \mathrm{C}(\%)$ & $\delta^{15} \mathrm{~N}\left(\%_{\% 0}\right)$ \\
\hline Ulva sD. (10)* & 33.78 & 1.21 & 27.92 & -24.7 & 8.7 \\
Ulva lactuca (5) & 34.01 & 2.05 & 16.59 & -25.2 & 7.1 \\
Entermotpha intestinalis (7) & 32.50 & 25.37 & 1.28 & -25.5 & 9.6 \\
Mangrove (3) & 55.14 & 3.87 & 14.25 & -25.6 & 12.2 \\
Reed (3) & 44.35 & 3.76 & 11.80 & -13.4 & 8.1 \\
Surface sediments (12) & 0.62 & 0.10 & 5.85 & -24.0 & 10.7 \\
\hline
\end{tabular}

*Bracketed number indicates the measured samples. 
At this time, terrestrial input was still dominant over the Yihju and San-liao-wan areas. When high $\delta^{15} \mathrm{~N}$ occurred, the waters were well mixed because of better circulation in the water body and either recycled nitrate from denitrification or ${ }^{15} \mathrm{~N}$-enriched ammonium became the important source of nitrogen for the primary producer. In addition, the well-mixed water could lead to oxic water columns, which also lead to heavy $\delta^{15} \mathrm{~N}$ in the sediments.

\subsection{Estimation of Terrigenous and Marine Contributions to the Coastal Sedimentary Organic Matter}

Possible sources of sedimentary organic matter in the coastal sediments of the study area are: terrestrial biologic, soil and lithic fragments from higher land areas; and organic matter derived from plankton and benthic sources. Using plots of stable carbon and nitrogen isotopes and $\mathrm{C} / \mathrm{N}$ ratios of organic matter are good tools for discriminating between organic matter sources. Furthermore, this approach can also show the mixing trend between terrestrial and marine source of organic matter (Meyers 1997; Ohkouchi et al. 1997; Muzuka and HillaireMarcel 1999; Muller and Voss 1999). We use the $\delta^{13} \mathrm{C}$ of C3: -26 to $-28 \%$ and C4: -12 to $-14 \%$ (Deines 1980; O'Leary 1981); the $\delta^{15} \mathrm{~N}$ of 3\% (Schoeninger and DeNiro 1984 and reference there in), and $\mathrm{C} / \mathrm{N}$ ratio of $>12$ as the terrestrial end member. On the other hand, the $\delta^{13} \mathrm{C}$ of -19 to $-28 \%$; the $\delta^{15} \mathrm{~N}$ of +7 to $+10 \%$ (Peters et al. 1978) and $\mathrm{C} / \mathrm{N}$ ratio of $<8$ are applied as the marine end member. Based on the plot of $\mathrm{C} / \mathrm{N}$ to $\delta^{13} \mathrm{C}$, we determine the organic matter source to be mainly aquatic with terrestrial input showing a mixing trend (Fig. 6). This implies that the source of organic matter is mainly from a similar source of low $\mathrm{C} / \mathrm{N}$ and stable $\delta^{13} \mathrm{C}$ such as the autochthonous primary producers in this sedimentary environment. The terrestrial input of plant tissue with a high $\mathrm{C} / \mathrm{N}$ ratio in this area is strong enough to indicate the main climate shift through C3 - C4 type species transition in vegetation.

In the San-liao-wan and Yihju cores, strong dilution by terrestrial input makes it difficult for us to clearly differentiate different organic nitrogen sources. But in the sediments of the Zai-kang core, the $\delta^{15} \mathrm{~N}$ varies within a wide range while $\delta^{13} \mathrm{C}$ and the $\mathrm{C} / \mathrm{N}$ ratio show relatively small variation. Figures 7 and 8 show the range of $\delta^{15} \mathrm{~N}$ vs. $\mathrm{C} / \mathrm{N}$ and $\delta^{15} \mathrm{~N}$ vs. $\delta^{13} \mathrm{C}$ values, respectively, for the dominant sources of sedimentary organic matter. Organic matter derived from marine algae, $\mathrm{C} 3$, and $\mathrm{C} 4$ land plants have overlapping $\delta^{15} \mathrm{~N}$ values; for these sources, $\delta^{13} \mathrm{C}$ and the $\mathrm{C} / \mathrm{N}$ ratio are better discriminators. However, there is an enriched ${ }^{15} \mathrm{~N}$ input for the Zai-kang core that causes a significant increase of $\delta^{15} \mathrm{~N}$. Thus, organic matter derived from this input is readily separable from other sources, even though the $\delta^{13} \mathrm{C}$ and $\mathrm{C} / \mathrm{N}$ ratio values overlap.

\section{CONCLUSIONS}

Organic carbon and nitrogen isotope values $\left(\delta^{13} \mathrm{C}, \delta^{15} \mathrm{~N}\right)$ and $\mathrm{C} / \mathrm{N}$ ratios measured in coastal core sediments allow us to trace organic matter provenance. The sea level lowered during MIS 4-2, leading to an environment with relatively strong erosion and less deposition. The sediments of three cores, collected from San-liao-wan, Zai-kang and Yihju, recorded this 
similar transition from shallow marine and lagoonal in to non-marine environmental deposition. As revealed in this study, before MIS 2, environmental conditions are relatively mild. This is supported by constant values for all the different markers used. The Yihju core recorded an early increase in terrestrial $\mathrm{C} 4$ species input, a feature absent in the other cores. This nonsynchronism may have been caused by regional variation in sedimentary condition. In MIS 2, simultaneously rising $\mathrm{C} / \mathrm{N}$ ratio and $\delta^{13} \mathrm{C}$ indicate increasing terrestrial $\mathrm{C} 4$ plant input, a feature that accords well with more arid climatic conditions.

In early MIS 1, the coastal area was once again inundated with seawater. The climate became more humid and mild, and more similar to the present-day. The $\delta^{13} \mathrm{C}$ and $\mathrm{C} / \mathrm{N}$ ratio both vary during initial MIS 1 but stabilize, indicating relative stability in the environment. This was a period when C3 type plant species became dominant. In the San-liao-wan and Yihju cores, strong dilution of terrestrial input makes it difficult for us to clearly discriminate between organic sources; however, the Zai-kang core appears to have been sourced from a shallow lagoon system, potentially preserving the $\delta^{15} \mathrm{~N}$ record from autochthonous primary producers. Regional organic source variation was revealed through high $\delta^{15} \mathrm{~N}$ values and constant $\mathrm{C} / \mathrm{N}$ ratios in MIS 1 of the Zai-kang core. This could possibly suggest that mangroves and macrophytes were the main aquatic organic matter source in the Zai-kang area during MIS 1.

Acknowledgements The authors would like to thank Dr. H. L. Hsieh, Dr. S. J. Kao and Dr. S. W. Lin for valuable discussion and advice. Special thanks are due to Mr. P. S. Chan, Mr. W. K. Ho, Mr. C. C. Hsieh and Mr. H. W. Jian for their help in isotope analysis and the laboratory work. This study was supported by National Science Council Grant NSC89-2116-M-002-048 to Dr. Y. G. Chen.

\section{REFERENCES}

Arthur, M. A., W. E. Dean, and L. M. Pratt, 1988:Geochemical and climatic effects of increased marine organic carbon burial at the Cenomanian/Turonian boundary. Nature, 335, 714-717.

Altabet, M. A., C. Pilskaln, R. Thunell, C. Pride, D. Sigman, F. Chavez, and R. Francois, 1999: The nitrogen isotope biogeochemistry of sinking particles from the margin of the Eastern North Pacific. Deep-Sea Res., 46, 655-679.

Altabet, M. A., and R. Francois, 1994: Sedimentary nitrogen isotopic ratio as a recorder for surface ocean nitrate utilization. Global Biogeochem., 8, 103-116.

Bordovskiy, O. K.,1965: Accumulation and transformation of organic substances in marine sediments. Mar. Geol., 3, 5-31.

Brandes, J. A., and A. H. Devol, 1997: Isotopic fractionation of oxygen and nitrogen in coastal marine sediments. Geochim. Cosmochim. Acta, 61, 1793-1801.

Deines, P., 1980: The isotopic composition of reduced organic carbon: In "Hand book of environmental isotope geochemistry", Amsterdam-Oxford-New York, 1, 329-406.

Emerson, S., and J. I. Hedges, 1988: Processes controlling the organic carbon content of open ocesn sediments. Paleoceanogr., 3, 621-634. 
Emmer, E., and R. C. Thunell, 2000: Nitrogen isotope fixation in Santa Barbara Basin sediments: Implications for denitrification in the eastern tropical North Pacific during the last 50,000 years. Paleoceanogr., 15, 377-387.

Fontugne, M. R., and J. M. Jonanneau, 1987: Modualtion of the particulate organic carbon flux to the ocean by a macrotidal estuary: evidence from measurements of carbon isotopes in organic matter from the Gironde system. Estuar. Coast. Shelf Sci., 24, 377387.

Ganeshram, R. S., T. F. Pedersen, S. E. Calvert, G. W. McNeill, and M. R. Fontugne, 2000: Glacial-interglacial variability in denitrification in the world's oceans: causes and consequences. Paleoceanogr., 15, 361-376.

Handley, L. L., and J. H. Raven, 1992: The use of natural abundance of nitrogen isotopes in plant physiology and ecology: commissioned review. Plant Cell Environ., 15, 965-985.

Horrigan, S. G., J. P. Montoya, J. L. Nevins, and J. J. McCarthy, 1990: Natural isotopic composition of dissolved inorganic nitrogen in Chesapeake Bay. Estuar. Coast. Shelf Sci., 30, 393-410.

Hsieh, H. L., W. Y. Kao., C. P. Chen, and P. J. Liu, 2000: Detrital flows through the feeding pathway of the oyster (Crassostrea gigas) in a tropical shallow lagoon: $\delta^{13} \mathrm{C}$ signals. Mar. Biol., 136, 677-684.

Linsley, B. K., and R. B. Dunbar, 1994: The late Pleistocene history of surface water $\delta^{13} \mathrm{C}$ in the Sulu Sea: Possible relationship to Pacific deepwater $\delta^{13} \mathrm{C}$ changes. Paleaceanogr., 9, 317-340.

Liu, T. K., and M. H. Hsia, 1998: Geochemical characteristics of sediments cores from Yihju, southwestern Taiwan: 1998 An. meet. Geol. Soc. China, 27-29.

Liu, T. K., Q. C. Sung, K. Y. Chen, Z. L. Pi, C. H. Yang, and P. H. Cheng, 1997: Tectonic subsidence and uplift in the Zeikang-Hopi area of southwestern Taiwan since the late Pleistocene. J. Geol. Soc. China, 40, 155-165.

Macko, S. A., and N. E. Ostrom, 1994: Pollution studies using stable isotopes. Stable Isotopes in Ecology and Environmental Science, Blackwell Sci. Publ., 45-62.

Martinson, D. G., N. G. Pisias, J. O. Hays, J. Imbrie, T. C. Moore, and J. Shackleton, 1987: Age dating and the orbital theory of the Ice Ages: Development of a high-resolution 0 to 300,000-yr chronostratigraphy. Quat.. Res., 27, 1-29.

Meyers, P., 1997: Organic geochemical proxies of palaeogeographic, paleolimnologic, and paleoclimatic processes. Org. Geochem., 27, 213-250.

Meyers, P. A., 1994: Preservation of elemental and isotopic source identification of sedimentary organic matter. Chem. Geol., 114, 289-302.

Michener, R. H., and Schell, D. M. 1994: Stable isotope ratios as tracers in marine aquatic food web. Stable Isotopes in Ecology and Environmental Science, Blackwell Sci. Publ., $138-157$.

Middelburg, J. J., and J. Nieuwenhuize, 1998: Carbon and nitrogen stable isotopes in suspended matter and sediments from the Shelde Esturay. Mar. Chem., 60, 217-225.

Minagawa, M., and E. Wada, 1984: Stepwise enrichment of ${ }^{15} \mathrm{~N}$ along food chains: further evidence, the relation between ${ }^{15} \mathrm{~N}$ and animal age. Geochim. Cosmochim. Acta, $\mathbf{4 8}$, 1135-1140. 
Muller, A., and M. Voss, 1999: The paleoenvironments of coastal lagoons in the southern Baltic Sea, II. $\delta^{13} \mathrm{C}$ and $\delta^{15} \mathrm{~N}$ ratios of organic matter- sources and sediments. Palaeogeogr. Paleoclimatol. Paleoecol., 145, 17-32.

Muzuka, A. N. N., and C. Hillaire-Marcel, 1999: Burial rates of organic matter along the eastern Canadian Margin and stable isotope constraints on its origin and diagenetic evolution. Mar. Geol., 160, 251-270.

Ohkouchi, N., H. Kawamura, and A. Taira, 1997: Fluctuation of terrestrial and marine biomakers in the western tropical Pacific during the last 23,000 years. Paleoceanogr., 12, 623-630.

O'Leary, M. H., 1981: Carbon isotope fraction in plants. Phytochem., 20, 553-567.

Ostrum, N. E., S. A. Macko, D. Deibel, and R. J. Thompson, 1997: Seasonal variation in the stable carbon and nitrogen isotope biogeochemistry of a coastal cold ocean environment. Geochim. Cosmochim. Acta, 61, 2929-2942.

Oung, J. N., Q. C. Sung, Y. D. Lin, T. K. Liu, and C. H. Yang, 1996: Alkane distribution and their geochemical significance in the Tzai-Kang core of the coastal plain, southwestern Taiwan. J. Geol. Soc. China, 40, 381-400.

Oung, J. N., Y. D. Lin, S. Y. Lin, Q. C. Sung, T. K. Liu, and C. H. Yang, 2001: Organic Geochemistry of Sediments in the Southwestern Coastal Plain, Taiwan. West. Pac. Earth Sci., 1, 373-390.

Owens, N. J. P., 1987: Natural variations in ${ }^{15} \mathrm{~N}$ in the marine environment, Advances in Marine Biology, Academic Press, 24, 389-451.

Owens, N. J. P., 1985: Variations in the natural abundance of ${ }^{15} \mathrm{~N}$ in estuarine suspended particulate matter: a specific indictor of biological processing. Estuar. Coast. Shelf Sci., 20, 505-510.

Peters, K. E., R. E. Sweeney, and I. R. Kaplan, 1978: Correlation of carbon and nitrogen stable isotope ratios in sedimentary organic matter.Limnol. Oceanogr., 23, 598-604.

Sachs, J. P., and D. J. Repeta, 1999: Oligotrophy and nitrogen fixation during eastern Meditereanean sapropel events. Science, 286, 2485-2488.

Schoneninger, M. J., and M. J. DeNiro, 1984: Nitrogen and carbon isotope composition of bone collagen from marine and terrestrial animals. Geochim. Cosmochim. Acta, 48, 625-639.

Shackleton, N. J., J. Imbrie, and M. A. Hall, 1983: Oxygen and carbon isotope record of East Pacific core V19-30: implications for the formation of deep water in the Late Pleistocene North Atlantic. Earth Planet. Sci. Lett., 65, 233-244.

Sigleo, A. C., and S. A. Macko, 1985: Stable isotope and amino acid composition of estuarine dissolved colloidal material. Marine and Estuarine Geochemistry, Lewis Publ., 29-46.

Schubert, C. J., and S. E. Calvert, 2001: Nitrogen and Carbon isotopic composition of marine and terrestrial organic matter in Arctic Ocean sediments: imolications for nutrient utilization and organic matter composition. Deep-Sea Res., 48, 789-810.

Tenzer, G. E., P. A. Meyers, J. A. Robbins, B. J. Eadie, N. R. Morehead, and M. B. Lansing, 1999: Sedimentary organic matter record of recent environmental changes in the St. Marys River ecosystem, Michigan-Ontario border. Org. Geochem., 30, 133-146. 
Thornton, S. F., and J. McManus, 1994: Application of organic carbon and nitrogen stable isotope and $\mathrm{C} / \mathrm{N}$ ratios as source indicators of organic matter provenance in estuarine systems: evidence from the Tay Estuary, Scotland. Estuar. Coast. Shelf Sci., 38, 219233.

Twichell, S. C., P. A. Meyers, and L. Diester-Haass, 2002: Significance of high C/N ratios in organic-carbon-rich Neogene sediments under the Benguela Current Upwelling System. Org. Geochem., 33, 715-722.

Tyson R. V., 1995: Abundance of organic matter in sediments: TOC, hydrodynamic equivalence, dilution and flux effects. Sedimentary Organic Matter: Organic Facies and Palynofacies, Chapman \& Hall, 81-118.

Voss, M., and U. Struck, 1997: Stable nitrogen and carbon isotopes as indicators of eutrophication of the Oder River (Baltic Sea). Mar. Chem., 59, 35-49.

Wada, E., M. Terazaki, Y. Kabaya, and T. Nemoto, $1987:{ }^{15} \mathrm{~N}$ and ${ }^{13} \mathrm{C}$ abundances in Antartic Ocean with Emphasis on the biogeochemical structure of the food web.Deep-Sea Res., 34, 829-841.

Wada, E., T. Kadonaga, and S. Matuse, $1975:{ }^{15} \mathrm{~N}$ abundance in nitrogen of naturally occurring substances and global assessment of denitrification from isotopic viewpoint. Geochem. J., 9, 139-148. 